\title{
The Effectiveness of Smokescreen Program on Smoking Prevention and Cessation
}

\author{
Aghnia Kamila' ${ }^{1}$ Teuku Tahlil ${ }^{1}$, Elly Wardani ${ }^{1}$
}

1 Magister Keperawatan Universitas Syiah Kuala Banda Aceh

\section{Article Info}

\section{Article History:}

Submitted: April 1 1', 2021

Accepted: May 24th, 2021

Published: May 31st, 2021

\section{Keywords:}

Smokescreen; Smoking;

Students; Self-efficacy

\begin{abstract}
Smoking is deviant behaviour that often affects adolescents and is addictive. The prevalence of smoking among adolescents is relatively high and harms health, so prevention efforts are needed. This study aims to know the smokescreen program's effectiveness on smoking prevention and cessation among students at Madrasah Tsanawiyah in Banda Aceh. The method used in this research is a quantitative quasi-experimental model with a nonequivalent control group design. This study's population was all students of class VII and VIII in two Madrasah Tsanawiyah in Banda Aceh, totalling 1221 students, and the sample was selected by purposive sampling technique as many as 302 respondents. Data was collected online using Zoom and Google Form and then analyzed using SPSS with Wilcoxon and Mann-Whitney test. The results showed that there was a significant difference in the mean value of self-efficacy ( $p$-value $0,000<0,005$ ) between the intervention group and the control group. The increase in the mean value of self-efficacy in the intervention group was higher than in the control group $(40,75>5,92)$. Thus, it can be concluded that the smokescreen program has effectiveness in smoking prevention and cessation. Respondents who get the smokescreen program intervention will have good knowledge and understanding of smoking to change their attitudes and views in a positive direction to refrain from smoking.
\end{abstract}

\section{PENDAHULUAN}

Merokok merupakan perilaku membakar, menghisap, dan menghirup salah satu produk tembakau yang mengandung nikotin dan tar [1]. World Health Organization (WHO) memperkirakan prevalensi perokok dunia pada populasi usia $\geq 15$ tahun sebanyak 20,2\%, diantaranya $14,3 \%$ pada usia $15-24$ tahun [2]. Prevalensi perokok di Indonesia tahun 2018 berjumlah $24,3 \%$ perokok setiap hari dan $4,6 \%$ perokok kadang-kadang. Sebanyak $0,7 \%$ perokok setiap hari berumur 10-14 tahun dan 1,4\% kadangkadang merokok. Sebanyak 12,7\% perokok umur 15-19 tahun merokok setiap hari dan 6,9\% kadang-kadang merokok. Adapun prevalensi perokok di Provinsi Aceh berada pada peringkat ke 7 dari 34 provinsi dengan jumlah penduduk umur $\geq 10$ tahun merokok setiap hari sebanyak $24,0 \%$ dan kadang-kadang merokok sebanyak 4,1\%,

Corresponding author:

Aghnia Kamila

aghniakamil4@gmail.com

Media Keperawatan Indonesia, Vol 4 No 2, May 2021

e-ISSN: 2615-1669

ISSN: 2722-2802

DOI: $10.26714 / \mathrm{mki} \cdot 4.2 .2021 .101-107$ 
dengan jumlah rata-rata 16,35 batang rokok yang dihisap [3].

Penggunaan tembakau pada masa remaja dapat menyebabkan perilaku menyimpang seperti perkelahian, perilaku seksual berisiko tinggi, dan penggunaan alkohol serta obat-obatan. Peristiwa ini menunjukkan bahwa membangkitkan motivasi secara dini dalam melakukan usaha untuk menghentikan kebiasaan merokok dan mencegah terjadinya ketergantungan terhadap tembakau karena motivasi adalah hal yang penting sebagai penggerak tingkah laku seseorang [4]. Perilaku merokok memiliki hubungan jangka panjang pada remaja karena perilaku tersebut dapat menjadi kebiasaan dan akan terus dilakukan hingga tumbuh dewasa. Oleh karena itu pengetahuan tentang resiko merokok merupakan hal yang penting dimiliki oleh remaja agar terhindar dari dampak buruk yang ditimbulkan dari efek merokok. Pengetahuan tenang bahaya rokok dapat membantu remaja untuk berpikir negatif terhadap rokok dan kemudian dengan pengetahuan tersebut remaja akan menganggap perilaku merokok sebagai perilaku menyimpang dan merugikan [5].

Meskipun begitu banyak upaya yang telah dilakukan pemerintah tetapi jumlah perokok aktif tidak berkurang terutama perokok di bawah umur [6]. Pemerintah Kota Banda Aceh menerbitkan Qanun Nomor 5 Tahun 2016 tentang Kawasan Tanpa Rokok (KTR), di mana peraturan tersebut bertujuan untuk melindungi kesehatan masyarakat dari bahaya akibat merokok, menciptakan lingkungan hidup yang baik dan sehat, membudayakan hidup sehat, menekan angka pertumbuhan perokok pemula dan membatasi ruang bagi perokok, pemasaran dan pengiklanan, serta memberikan sanksi Tindak Pidana Ringan (Tipiring) kepada perokok dan kepada produsen yang melakukan promosi di area Kawasan Tanpa Rokok (KTR) yang telah ditentukan [7].
Salah satu metode yang dapat menghentikan perilaku merokok yaitu dengan smokescreen yang merupakan metode dengan mengandalkan perubahan pengetahuan dan perilaku melalui intervensi video dan game yang dapat dilakukan dalam mencegah dan menghentikan perilaku merokok di kalangan remaja [8,9]. Smokescreen adalah salah satu metode pencegahan dini perilaku merokok yang berfokus pada mengubah pengetahuan, self-efficacy (keyakinan diri), perilaku, dan pandangan norma terkait dengan rokok yang dapat dipelajari dari video dan game yang dimainkan oleh partisipan. Intervensi video dan game yang berfokus pada perubahan pengetahuan dan perilaku memberikan pengaruh terhadap pencegahan perilaku merokok pada kelompok remaja yang berusia 11-14 tahun [10]. Demikian pula dengan penelitian lainnya yang menunjukkan adanya hubungan self-efficacy dengan perilaku merokok pada remaja [11].

Menurut Lu dkk [12] game memiliki potensi dalam meningkatkan kesehatan dan sangat direkomendasi untuk kaum remaja. Karena karakteristik game yang mengandung narasi atau cerita dapat memengaruhi kognisi, dan berpotensi mempengaruhi perilaku kesehatan pemain game. Video promosi kesehatan merupakan media yang tepat bagi remaja, karena jika diperlihatkan secara terus-menerus maka akan memberikan dampak positif pada pribadinya [13]. Oleh karena artikel ini bertujuan mengetahui efektivitas program smokescreen terhadap pencegahan dan penghentian merokok pada siswa madrasah tsanawiyah.

\section{METODE}

Penelitian ini menggunakan metode kuantitatif pendekatan eksperimen semu (quasi experiment) dengan desain non equivalent control group design. Kelompok intervensi diberikan program smokescreen berupa video dan game menyusun kata dan kelompok kontrol tidak diberikan program 
smokescreen. Penentuan kelompok kontrol dan kelompok intervensi sesuai dengan kriteria penelitian. Kedua kelompok tersebut diberikan pre-tes untuk mengetahui self-efficacy (keyakinan siswa). Setelah itu diberikan program smokescreen pada kelompok intervensi dengan menggunakan sistem online melalui aplikasi Zoom dan Google Form yang dilakukan pada akhir pelajaran Penjaskes. Langkah terakhir adalah memberikan posttes kepada kedua kelompok untuk mengetahui self-efficacy.

Kriteria sampel ditentukan dengan teknik purposive yaitu siswa/i kelas VII dan VIII di dua Madrasah Tsanawiyah di Banda Aceh yang bertemu dengan peneliti ketika akhir sesi pembelajaran online Penjaskes. Sampel yang diambil dalam penelitian ini adalah siswa kelompok intervensi berjumlah 151 siswa di MTSN Model Banda Aceh dan kelompok kontrol berjumlah 151 siswa di MTSN 4 Rukoh Banda Aceh. Kelompok kontrol dan intervensi ditentukan dengan cara dipilih berdasarkan beberapa alasan bahwa kedua madrasah berada di daerah yang memungkinkan siswa terpengaruh untuk merokok dan data awal yang diperoleh tentang kedua madrasah tersebut ditemukan bahwa terdapat siswa yang pernah merokok di dalam maupun dilingkungan sekolah.

Alat pengumpulan data yang digunakan dalam penelitian ini adalah kuesioner baku yang di adaptasi dari penelitian Lawrance [14] untuk mengetahui self-efficacy (keyakinan diri) terhadap efek yang bisa ditimbulkan akibat rokok. Kuesioner telah diuji validitas dan reliabilitasnya pada 20 siswa di salah satu MTsN di Banda Aceh menggunakan teknik korelasi product moment (r) dengan nilai koefisien korelasi antara 0,73 sampai 0,86 dan nilai Crombach's alpha sebesar 0,76, yang menunjukkan bahwa kuesioner tersebut cukup reliabel. Uji statistik yang digunakan adalah wilcoxon untuk melihat perbedaan skor sebelum dan sesudah perlakuan, dan mann whitney untuk melihat perbedaan skor sesudah perlakuan antara kelompok intervensi dan kelompok kontrol menggunakan bantuan program komputer SPSS 21.0 for windows.

Penelitian ini dilaksanakan setelah dinyatakan lulus kajian etik oleh Komite Etik Penelitian Fakultas Keperawatan Universitas Syiah Kuala pada tanggal 2 Oktober 2020 dengan kode penelitian 112001210920.

\section{HASIL}

Penelitian ini dilaksanakan di MTsN Model dan MTsN 4 Banda Aceh yang terletak di daerah perkotaan dan sekitar lingkungan Madrasah terdapat banyak aktivitas masyarakat yang berkaitan dengan kebiasaan merokok. Karakteristik responden dalam penelitian ini dikelompokkan ke dalam kategori usia, kelas, jenis kelamin.

Tabel 1

Karakteristik Responden Kelompok Kontrol dan Kelompok Intervensi $(\mathrm{n}=302)$

\begin{tabular}{|c|c|c|c|c|c|}
\hline \multirow[t]{2}{*}{ Indikator } & \multicolumn{2}{|c|}{$\begin{array}{l}\text { Kelompok } \\
\text { Intervensi }\end{array}$} & \multicolumn{2}{|c|}{$\begin{array}{c}\text { Kelompok } \\
\text { Kontrol }\end{array}$} & \multirow[t]{2}{*}{$\mathrm{p}$} \\
\hline & $\mathrm{f}$ & $\%$ & $\mathrm{f}$ & $\%$ & \\
\hline \multicolumn{6}{|l|}{ Usia } \\
\hline 12 Tahun & 41 & 27,1 & 37 & 24,5 & \multirow{4}{*}{0,046} \\
\hline 13 Tahun & 83 & 55,0 & 80 & 53,0 & \\
\hline 14 Tahun & 27 & 17,9 & 33 & 21,9 & \\
\hline 15 Tahun & & & 1 & 0,7 & \\
\hline \multicolumn{6}{|l|}{ Kelas } \\
\hline VII & 73 & 48,3 & 67 & 44,4 & \multirow[t]{2}{*}{-} \\
\hline VIII & 78 & 51,7 & 84 & 55,6 & \\
\hline \multicolumn{6}{|l|}{ Jenis Kelamin } \\
\hline Laki-Laki & 60 & 39,7 & 71 & 47,0 & \multirow{2}{*}{0,000} \\
\hline Perempuan & 91 & 60,3 & 80 & 53,0 & \\
\hline
\end{tabular}

Total responden dalam penelitian ini sebagaimana tersaji dalam tabel 1 berjumlah 302 responden dengan komposisi responden lebih banyak berjenis kelamin perempuan (58,9\%). Mayoritas responden berusia 13 tahun (53,9\%) dan berada di kelas VIII $(53,6 \%)$. Rata-rata karakteristik responden pada kelompok kontrol dan kelompok intervensi memilik proporsi yang sama berdasarkan usia, kelas, dan jenis kelamin. 
Hasil penelitian menunjukkan bahwa grade rerata self-efficacy pada kelompok intervensi sebelum diberikan intervensi berada pada kategori rendah $(167,77)$ dengan nilai terendah 86 dan nilai tertinggi 180 dengan confidence interval 95\%. Hasil pengukuran pertama pada kelompok kontol juga menunjukkan hasil yang serupa yaitu rerata self-efficacy berada pada kategori lemah $(170,51)$ dengan nilai tertinggi 180 dan 83 nilai terendah dengan tingkat kepercayaan 95\%. Tidak terdapat perbedaan nilai rerata self-efficacy ( $\mathrm{p}$ value $0,192>0,005$ ) yang bermakna antara kelompok intervensi (sebelum intervensi) dan kelompok kontrol pada pengukuran pertama.

Hasil penelitian menunjukkan bahwa setelah dilakukan intervensi terjadi peningkatan rerata self-efficacy pada kelompok intervensi sehingga self-efficacy kelompok intervensi berada pada kategori tinggi dengan nilai rata-rata 208,52, dengan nilai tertinggi 216 dan terendah 121. Grade rerata self-efficacy pada kelompok kontrol pada pengukuran kedua berada pada kategori rendah $(176,45)$ dengan nilai tertinggi 198 dan nilai terendah 87 (confiden interval 95\%). Rerata self-efficacy kelompok intervensi (setelah intervensi) dan kelompok kontrol pada pengukuran kedua menunjukkan adanya perbedaan yang signifikan ( $p$ value $0,000<0,005$ ) dengan nilai perbedaan rerata yaitu 32,093 .

Hasil penelitian menunjukkan terdapat peningkatan nilai self-efficacy sebelum dan sesudah diberikan intervensi yaitu sebesar 40,75 pada kelompok intervensi dan peningkatan sebesar 5,92 pada kelompok kontrol. Peningkatan nilai self-efficacy pada kelompok intervensi sebelum dan sesudah diberikan intervensi menunjukkan adanya perbedaan nilai self-efficacy yang bermakna (p value $0,000<0,005$ ). Pada kelompok kontrol juga terdapat perbedaan yang bermakan antara pengukuran pertama dan kedua ( $\mathrm{p}$ value $0,000<0,005)$. Rerata peningkatan nilai self-efficacy pada kelompok intervensi jauh lebih tinggi dari pada kelompok kontrol $(40,75>5,92)$.

Tabel 2

Perbedaan self-efficacy kelompok intervensi dan kelompok kontrol

\begin{tabular}{lccc}
\hline \multicolumn{1}{c}{ Indikator } & $\begin{array}{c}\text { Kelompok } \\
\text { intervensi }\end{array}$ & $\begin{array}{c}\text { Kelompok } \\
\text { kontrol }\end{array}$ & $\mathrm{p}$ \\
\hline $\begin{array}{l}\text { Self-efficacy } \\
\text { sebelum dilakukan }\end{array}$ & $\begin{array}{c}167,77 \\
( \pm 29,957)\end{array}$ & $\begin{array}{c}170,51 \\
( \pm 27,264)\end{array}$ & $0,192^{*}$ \\
$\begin{array}{l}\text { intervensi } \\
\begin{array}{l}\text { Self-efficacy setelah } \\
\text { dilakukan intervensi }\end{array}\end{array} \begin{array}{c}208,52 \\
( \pm 17,812)\end{array}$ & $\begin{array}{c}176,43 \\
( \pm 24,865)\end{array}$ & $0,000^{*}$ \\
\hline $\mathrm{p}$ & $0,000^{* *}$ & $0,000^{* *}$ & \\
\hline
\end{tabular}

* Mann-Whitney test

** Wilcoxon test

\section{PEMBAHASAN}

Penelitian ini dilaksanakan di dua Madrasah Tsanawiyah di Kota Banda Aceh yaitu MTsN Model sebagai kelompok intervensi dan MTsN 4 Rukoh sebagai kelompok kontrol. Hasil penelitian ini menunjukkan bahwa kelompok intervensi dan kelompok kontrol memiliki karakteristik yang sama. Karakteristik individu/responden perlu mendapat perhatian karena memiliki hubungan dengan perilaku, termasuk perilaku merokok. Salah satu hasil penelitian menyatakan bahwa usia 11-14 tahun merupakan kelompok usia remaja awal yang mudah terpengaruh oleh rokok. Salah satu upaya efektif yang dapat dilakukan untuk mencegah perilaku merokok pada usia 11-14 tahun adalah penggunaan intervensi video dan game [10].

Penggunaan intervensi video dan game dapat memberikan pengaruh terhadap pencegahan perilaku merokok pada remaja awal yang berusia 11-14 tahun apabila intervensi tersebut difokuskan pada perubahan pengetahuan dan perilaku. Usaha pencegahan dan penghentian perilaku merokok pada remaja awal menjadi sesuatu yang penting dilakukan karena perilaku merokok dapat berdampak negatif pada fungsi kognitif, dan perokok pada usia dini beresiko mengalami gangguan memori yang lebih buruk dan dapat mengalami kerusakan otak [15]. 
Penelitian ini memberikan intervensi smokescreen yang berupa video dan game pada siswa yang menjadi responden pada kelompok intervensi. Hasil penelitian menunjukkan bahwa intervensi yang dilakukan pada siswa kelompok intervensi terbukti dapat meningkatkan self-efficacy siswa untuk berhenti merokok. Dengan demikian dapat dinyatakan bahwa program smokescreen dapat dijadikan salah satu model intervensi untuk mencegah dan menghentikan perilaku merokok pada siswa madrasah tsanawiyah. Program smokescreen ini menjadi efektif karena merupakan suatu program yang berisi video dan game yang menyasar remaja yang berusia antara 11-14 tahun sebagai upaya untuk mencegah dan menghentikan perilaku merokok, terutama mereka yang berjenis kelamin laki-laki yang banyak terpapar perilaku merokok [16]. Hasil tersebut senada dengan penelitian lainnya yang menyatakan bahwa intervensi video game yang berfokus pada perubahan pengetahuan dan perilaku memberikan pengaruh terhadap pencegahan perilaku merokok pada kelompok remaja awal yang berusia antara 11-14 tahun [10].

Smokescreen menjadi salah satu metode yang menarik, efektif dan efisien karena berfokus pada mengubah pengetahuan, kesadaran diri, perilaku, dan pandangan norma terkait dengan rokok yang dapat dipelajari dari video dan game yang dimainkan oleh partisipan [9]. Dengan paparan video dan game tentang bahaya merokok akan memberikan pengetahuan tentang bahaya kesehatan yang ditimbulkan dan hal tersebut dapat memicu niat perokok untuk berhenti merokok. Di samping itu, efektivitas smokescreen dalam penelitian ini diukur dari perubahan selfefficacy responden setelah diberikan intervensi. Penelitian lain menyebutkan bahwa self-efficacy (keyakinan diri) memiliki hubungan yang signifikan dengan perilaku merokok pada remaja. Self-efficacy merupakan kepercayaan dan kemampuan yang dimiliki seseorang untuk menguasai situasi dan menghasilkan sesuatu yang positif. Apabila self-efficacy seorang pada remaja tinggi maka akan menolak untuk merokok, sedangkan pada remaja yang memiliki self-efficacy rendah maka akan lebih tertarik untuk merokok [17].

Berdasarkan hasil penelitian didapatkan bahwa pemberian intervensi program smokescreen yang berupa video dan game pada siswa kelompok intervensi berhasil meningkatkan self-efficacy siswa untuk berhenti dan mencegah perilaku merokok. Setelah diberikan intervensi, mayoritas responden penelitian memiliki self-efficacy tinggi dalam hal mencegah dan berhenti merokok, padahal sebelum diberikan intervensi, rerata self-efficacy siswa berada pada kategori rendah. Sedangkan pada kelompok kontrol yang tidak diberikan intervensi smokescreen yang berupa video dan game, self-efficacy hanya meningkat sedikit dan tetap berada pada kategori selfefficacy rendah. Peningkatan self-efficacy siswa dalam penelitian ini memberikan kesimpulan bahwa pemberian intervensi smokescreen efektif untuk mencegah dan menghentikan perilaku merokok pada remaja usia 11-14 tahun karena program smokescreen dapat meningkatkan selfefficacy siswa. Hasil penelitian ini didukung oleh penelitian lainnya yang menyatakan bahwa self-efficacy yang tinggi dapat mencegah perilaku merokok remaja $[11,18]$.

Begitu pula dengan penelitian lainnya yang mengungkapkan bahwa self-efficacy memiliki hubungan dengan perilaku merokok dan self-efficacy terbukti dapat mempengaruhi niat remaja dalam merokok karena keyakinannya pada bahaya atau manfaat merokok dapat mempengaruhi niat remaja untuk merokok atau tidak merokok $[19,20]$. Dengan demikian, penulis berkesimpulan bahwa self-efficacy yang kuat pada individu berdampak pada rasa yakin individu untuk melakukan perilaku sehat dan menghindari perilaku berisiko seperti merokok. self-efficacy yang kuat pada individu akan mendorong lahirnya perilaku sehat, sebaliknya self-efficacy 
rendah tidak dapat mendorong terciptanya perilaku sehat pada individu. Singkatnya, self-efficacy yang kuat tidak mudah dipengaruhi untuk melakukan perilaku merokok dan perilaku yang dapat merugikan kesehatan.

Hasil penelitian pada kelompok intervensi didapatkan bahwa terdapat perbedaan efektivitas sesudah dan sebelum diberikan intervensi. Hasil ini menunjukkan bahwa setelah pemberian smokescreen program yang dilakukan dengan menonton video dan bermain game yang dirancang khusus untuk pencegahan dan penghentian merokok sangat berpengaruh pada remaja dalam meningkatkan pengetahuan dan pemahaman tentang rokok. Hasil penelitian ini dapat dipahami karena pada dasarnya smokescreen merupakan metode dengan mengandalkan perubahan pengetahuan dan perilaku melalui intervensi video dan game yang dapat dilakukan dalam mencegah dan menghentikan perilaku merokok di kalangan remaja [8]. Oleh karena itu hasil penelitian ini memperkuat penelitian lainnya yang intervensi video efektif digunakan sebagai media kenaikan pangkat kesehatan khususnya mengatasi kasus perilaku merokok pada remaja, karena jika diperlihatkan secara monoton maka akan memberikan pengaruh yang kuat pada pengendalian diri untuk tidak merokok \& percaya diri menolak merokok serta dapat memotivasi diri untuk nir merokok $[10,13]$.

Faktor lain yang mendukung efektivitas smokescreen sebagai media untuk mencegah dan menghentikan perilaku merokok adalah karena program smokescreen berisi video dan game yang pada dasarnya merupakan media audio visual. Beberapa penelitian telah membuktikan bahwa audio visual merupakan media yang efektif untuk meningkatkan pengetahuan dan sikap remaja tentang bahaya rokok, serta sangat efektif jika digunakan untuk sebagai sarana pendidikan kesehatan $[21,22]$. Hal ini berarti bahwa peningkatan self-efficacy atau keyakinan diri siswa untuk mencegah dan berhenti merokok yang tinggi turut dipengaruhi oleh metode dan media yang digunakan dalam penelitian. Hal ini senada dengan penelitian lainnya yang menyatakan bahwa pemilihan metode dan media penyampaian informasi dapat memberikan efek yang signifikan terhadap peningkatan pengetahuan. Singkatnya, penyampaian informasi dipengaruhi oleh metode dan media yang digunakan [23]. Terakhir, efektivitas smokescreen program dalam penelitian ini juga didukung oleh pernyataan responden pasca intervensi, di mana $95.0 \%$ responden sangat yakin bisa menahan diri untuk tidak merokok, dan 5\% responden yang merokok pernah mencoba berhenti untuk merokok dan semua responden yang merokok berniat berhenti merokok.

\section{SIMPULAN}

Hasil penelitian menunjukkan terdapat perbedaan rerata nilai self-efficacy siswa yang bermakna antara kelompok intervensi yang diberikan program smokescreen dengan kelompok kontrol tidak diberikan intervensi. Rerata peningkatan nilai selfefficacy pada kelompok intervensi yang diberikan program smokescreen jauh lebih tinggi dibandingkan kelompok kontrol. Dengan demikian dapat disimpulkan bahwa smokescreen program memiliki efektivitas terhadap pencegahan dan penghentian merokok pada siswa. Responden yang mendapatkan intervensi smokescreen program akan mempunyai pengetahuan dan pemahaman yang baik tentang rokok, sehingga dapat mengubah sikap dan pandangan ke arah positif yang memicu remaja dapat menahan diri untuk tidak merokok.

\section{UCAPAN TERIMAKASIH}

Penulis mengucapkan terima kasih yang sebesar-besarnya kepada semua pihak yang telah terlibat dalam membantu dalam penelitian ini. 


\section{REFERENSI}

[1] Kemenkes RI. Peraturan Menteri Kesehatan Republik Indonesia Nomor 28 Tahun 2013 tentang Pencantuman Peringatan Kesehatan Dan Informasi Kesehatan Pada Kemasan Produk Tembakau 2013.

[2] WHO. Who global report on trends in prevalence of tobacco smoking 2000-2025, second edition. Geneva: World Health Organization; 2018.

[3] Kemenkes. Salam Sehat! Semoga fakta yang disajikan dalam buku ini, bermanfaat untuk perbaikan perencanaan pembangunan kesehatan. Lap Riskesdas Nas 2018 2018:120.

[4] Banerjee SC, Greene K. Sensation Seeking and Adolescent Cigarette Smoking: Examining Multiple Pathways in Cross-Sectional Data. Open Addict J 2009;2:12-20. https://doi.org/10.2174/18749410009020100 12.

[5] Munir M. Pengetahuan dan Sikap Remaja Tentang Risiko Merokok pada Santri Mahasiswa di Asrama UIN Sunan Ampel Surabaya. Klorofil 2018;1:93-104.

[6] Ramdhani L, Laili F, Jumlah Z. Cigarette Vending Machine Dan Cicard "Solusi Alternatif Untuk Mengurangi Jumlah Perokok Aktif Dibawah Umur." J Ilm Mhs Fak Kesehat Masy Univ Diponegoro 2014;4:97412.

[7] Qanun Kota Banda Aceh. Kawasan Tanpa Rokok. Banda Aceh, Indonesia: 2016.

[8] Forsyth SR, Malone RE. Smoking in video games: A systematic review. Nicotine Tob Res 2016;18:1390-8.

https://doi.org/10.1093/ntr/ntv160.

[9] Duncan LR, Hieftje KD, Pendergrass TM, Sawyer BG, Fiellin LE. Preliminary investigation of a videogame prototype for cigarette and marijuana prevention in adolescents. Subst Abus 2018;39:275-9.

https://doi.org/10.1080/08897077.2018.1437 862.

[10] Pentz MA, Hieftje KD, Pendergrass TM, Brito SA, Liu M, Arora T, et al. A videogame intervention for tobacco product use prevention in adolescents. Addict Behav 2019;91:188-92. https://doi.org/10.1016/j.addbeh.2018.11.016.

[11] Haryati W, Abdullah A, Bakhtiar. Self Efficacy dan Perilaku Merokok Remaja. J Ilmu Keperawatan 2015;3:2338-6371.

[12] Lu AS, Baranowski T, Thompson D, Buday R. Story Immersion of Videogames for Youth Health Promotion: A Review of Literature. Games Health J 2012;1:199-204. https://doi.org/10.1089/g4h.2011.0012.
[13] Saleh YR, Arya IF, Afriandi I. Film yang Efektif Sebagai Media Promosi Kesehatan bagi Masyarakat. J Sist Kesehat 2016;2:70-8. https://doi.org/10.24198/jsk.v2i2.11245.

[14] Lawrance L. Validation of a self-efficacy scale to predict adolescent smoking. Health Educ Res 1989;4:351-60. https://doi.org/10.1093/her/4.3.351.

[15] Jacobsen LK, Krystal JH, Mencl WE, Westerveld M, Frost SJ, Pugh KR. Effects of smoking and smoking abstinence on cognition in adolescent tobacco smokers. Biol Psychiatry 2005;57:5666.https://doi.org/10.1016/j.biopsych.2004.10. 022.

[16] Pangestu AW. Faktor-Faktor yang Berhubungan dengan Perilaku Merokok Shisha pada Siswa SMA X di Kota Semarang. Kesehat Masy 2017;5:489-99.

[17] Santrock. J. Perkembangan anak. Jakarta: PT. Erlangga; 2007

[18] Riet J van 't, Ruiter RAC, Werrij MQ, de Vries H. The influence of self-efficacy on the effects of framed health messages. Eur J Soc Psychol 2008;38:800-9.

https://doi.org/10.1002/ejsp.496.

[19] Schuck K, Otten R, Kleinjan M, Bricker JB, Engels RCME. Self-efficacy and acceptance of cravings to smoke underlie the effectiveness of quitline counseling for smoking cessation. Drug Alcohol Depend 2014;142:269-76 https://doi.org/10.1016/j.drugalcdep.2014.06. 033.

[20] Mangunsong RR, Murti B, Wijaya M. Association between Cigarette Package Warning Messages, Self-Efficacy, and Smoking Behavior among Students at Health Polytechnic in Surakarta, Indonesia 2016;1:44-52.

[21] Wardhani AC, Sari SYI, Badudu DF. Effectiveness of Print and Audiovisual Media in Breast Cancer Education to High-School Students. Althea Med J 2017;4:518-23. https://doi.org/10.15850/amj.v4n4.1261.

[22] Siregar S, Rochadi K, Maas LT. the Effect of Audio-Visual Media on Adolescents' Knowledge and Attitude Toward Smoking Dangerous At Secondary High School 2 Halongonan Subdistrict, Indonesia. Int J Nurs Heal Serv 2019;2:164-71. https://doi.org/10.35654/ijnhs.v2i3.147.

[23] Notoatmodjo S. Promosi kesehatan dan ilmu perilaku. Jakarta: Rineka Cipta; 2014. 